\title{
Corporate contracting around defective regulations: The Daimler-Chrysler case
}

\author{
Theodor Baums
}

The article describes the legal structure of the Daimler-Chrysler merger. It asks why this specific structure rather than another cheaper way was chosen. This leads to the more general question of the pros and cons of mandatory corporate law as a regulatory device. The article advocates an "optional" approach: The legislator should offer various menus or sets of binding rules among which the parties may choose. (JEL: ...)

\section{I. "Competition" of mandatory rules}

The classical approach to avoid or correct market failure is regulation. Our mandatory corporate law aims at avoiding or mitigating principal-agent problems between shareholders and managements, collective action problems in companies with widely spread ownership, and opportunistic behavior in the relationship between small investors and controlling shareholders. There are however, additional problems with the regulatory approach of employing mandatory law. ${ }^{1}$ As far as mandatory law means statutory law, adaptation to new circumstances may be particularly cumbersome and difficult. Statute law tends to petrify especially where vested interests stand in the way of a change. A further problem with mandatory law is that the rulesetting institutions will very often be provided with only limited information, both as far as the spectrum of possible constellations and different possible solutions are concerned.

One way out of this dilemma could be a competition of regulators: A working competition of (state or national) regulators rewarding the most efficient regulator would force them to adapt more quickly to changing circumstances (ROMANO [1993]; SPINDLER [1998]). But [1998]. 
competition between regulators might not work well for several reasons (BAUMS [1996]; BEBCHUK/ROE [1998]).

Whereas competition of regulators is thought to put pressure on a defective system from the outside, the regulatory system can also itself, at least to a certain extent, provide for selfcorrection from within the system. It can offer various optional solutions, albeit each of them binding, and leave it to the market to find the most suitable and efficient. There are several instances where the legislator has already employed this regulatory technique. The choice between a one-tier or two-tier board in French corporate law comes to mind as a famous example (GUYON [1996], 319). Whereas in this case the parties are free to choose between two different structures, corporate law admits in other cases to achieve a goal on different paths. Defective rules can thus be circumvented. The result itself may not be quite the same as originally wanted, and the way to it may be more costly. Nevertheless it is chosen in order to achieve a solution without incurring the cost and problems connected with defective regulation. The latter is thus rendered obsolete by practice which "contracts around it". Of course, "contracting around" a binding regulation by choosing another binding form is not always feasible. The cost of contracting around may be simply too high. Or the legislator may have blocked all other ways. At this point competition between regulators will have to come into play.

The regulatory approach of a competition between mandatory rules must not be confused with the passing of non-mandatory provisions or enabling rules by the legislator. The latter is not regulation in its specific sense. Non-mandatory provisions leave it to the parties whether they make use of these rules or invent new ones. These rules reduce transaction costs by providing a subsidiary regime for cases where the parties have deliberately chosen not to contract otherwise, and they fill in gaps where the parties have simply forgotten to do so.

The theory of self-correction in our system of mandatory (corporate) law is still in its infancy, and reflections on this point are very abstract (TEUBNER [1989]). On the contrary, classical continental systematic legal thinking has an inherent tendency to develop principles which are 
then generalized, ${ }^{2}$ and to fill "gaps" by analogy to norms which were originally developed for other circumstances. ${ }^{3}$ Contractors' choosing of a different way to reach the same or a similar result is thus often viewed with suspicion and confronted by the reproach of circumvention. But very often the choice of a different arrangement by the parties simply reveal the defects of alternatives. By analyzing such arrangements we get to know these defects better and can improve our law as with comparative studies. Admitting competition between rules could hence make our corporate law more efficient. Of course that is not competition in its true sense as the rule-maker is a single offeror offering various options or menus which the parties may choose.

The recent Daimler-Chrysler merger teaches us several interesting lessons in this respect. In what follows I will first describe the structure of this merger according to the available information on this deal in the media. ${ }^{4}$ Further sections will then try to explain why perhaps more obvious and less costly alternatives could not be taken.

\section{The structure of the merger}

There will be no true merger between Daimler-Benz Aktiengesellschaft and Chrysler Inc. Rather, a private German bank, Oppenheim $\mathrm{KGaA}$, has founded a wholly-owned subsidiary ("Oppenheim Aktiengesellschaft", now renamed "Daimler-Chrysler Aktiengesellschaft"). The Chrysler shares will be collected by an American trustee by means of a reverse triangular merger (cf. IV., below). This trustee will then bring in these shares into Oppenheim in exchange for Oppenheim shares. Hence Chrysler Inc. will afterwards be a 100 percent subsidiary of Oppenheim AG.

Cf. Larenz/Canaris [1995], chapter 6. For a different view Schanze [1995], 162 who argues that courts have sympathy for parties who try to escape regulation by use of, among other methods, new forms of contract.

3 Cf. Larenz/Canaris [1995], chapter 5.

$4 \quad$ Cf. Financial Times, May 14, 1998, p. 19; Wirtschaftswoche, Nr. 21, May 14, 1998, pp. 50 ff.; Der Spiegel, Nr. 20, May 11, 1998, pp. 104 ff.; Welt am Sonntag, Nr. 20, May 17, 1998, p. 53. The Business Combination Agreement between Daimler-Benz and Chrysler is also (as a part of Form 8$\mathrm{K}$ filed with the SEC, Washington, D.C.) available via Internet. 
As to the German side, Oppenheim AG will make a public offer to the Daimler shareholders and ask them to swap their shares for Oppenheim stock. Shareholders who do not accept this offer will remain for the time being in Daimler-Benz AG. In a second step, Daimler-Benz AG will however be merged into Oppenheim AG with the effect that all shareholders of the former Daimler-Benz AG will hold Oppenheim shares, the old Daimler-Benz shares will become invalid, and the legal entity Daimler-Benz AG will be dissolved. As an effect of the merger all holdings of Daimler-Benz (like Mercedes-Benz, Dasa, debis) will be transferred to Oppenheim AG. 

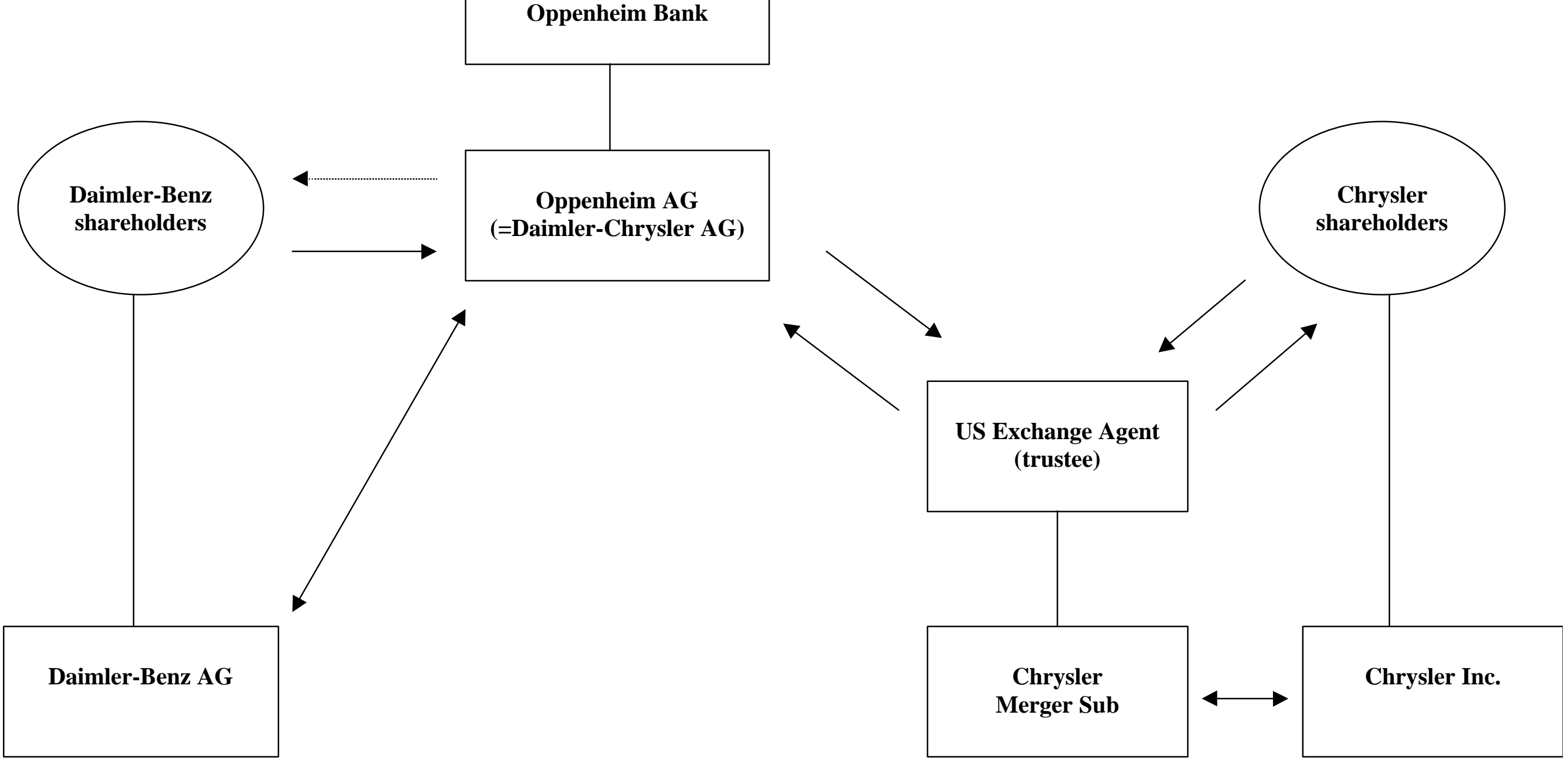

\section{1. step}

public offer to swap Daimler-Benz

shares for Daimler-Chrysler shares

\section{2. step}

merge Daimler-Benz into Daimler-

Chrysler AG

\section{1. step}

US trustee collects Chrysler shares by triangular merger

\section{2. step}

trustee brings Chrysler shares into Oppenheim for Oppenheim shares and hands them out to former Chrysler shareholders 


\section{Why no direct merger of Daimler-Benz AG and Chrysler Inc.?}

Why did the parties to the agreement, Chrysler of America and Daimler-Benz Aktiengesellschaft, not choose a direct merger of both firms? Apparently both sides very quickly agreed that a German rather than an American holding company should be formed, perhaps for tax reasons and simply because Daimler-Benz is the bigger company. ${ }^{5}$ A direct merger of Chrysler Inc. into Daimler-Benz AG would have transformed all Chrysler shares into DaimlerBenz shares. The complicated transactions which have actually been chosen (formation of a new company "Oppenheim AG"; triangular merger of Chrysler with a trustee company in the U.S.; public offer to Daimler shareholders with a subsequent merger of Daimler-Benz into Oppenheim) would not have been necessary.

A practical argument against a direct merger is that it would dissolve Chrysler. Chrysler Inc. would disappear as a legal entity. Retransferring its assets on a new "Chrysler" subsidiary could be costly. But, more importantly, there are also regulatory obstacles to direct transborder mergers. The German Transformation Act (Umwandlungsgesetz) regulating, inter alia, mergers provides in its $\S 1$ that it is applicable on "transformations" of entities with a domestic seat only. This provision itself does not exclude the merger of domestic with foreign companies. But other norms of this Act, like e. g. the provisions on filings with the commercial registers for both companies, indicate that the legislator had in mind only mergers of domestic firms. In practice, some courts (which administer the commercial register in Germany) have refused to register transnational mergers whereas others accepted them. ${ }^{6}$ Of course this uncertainty renders attempts at transborder merger an impossible solution, at least for big publicly held companies.

Our Transformation Act does not inhibit transborder mergers because of a general negative assessment or attitude towards such transactions in general (at least as mergers from abroad into German companies are concerned ${ }^{7}$ ). It is only that the Act fails to provide for the

5 Share capital Daimler-Benz: DM 35 bn, Chrysler DM 20 bn; turnover Daimler-Benz DM 124 bn, Chrysler DM 105 bn; profit (before tax) Daimler-Benz DM 4,2 bn; Chrysler DM 7,9 bn; employees Daimler-Benz 300,000; Chrysler 121,000 (numbers as of 1997).

$6 \quad$ References in Lutter, [1996], § 1 margin No. 5, footnote 8.

7 For mergers of German (co-determined) companies into foreign companies cf. Grossfeld, in: v. Staudingers Kommentar zum Buergerlichen Gesetzbuch, Internationales Gesellschaftsrecht, 13.ed. 1993, note 640 . 
necessary technical adjustments. Hence parties have to contract around these defective rules and incur the high costs connected with alternative ways. Extending the Transformation Act to transborder mergers would reduce these costs, open up a further alternative and improve the efficiency of our corporate law system.

\section{Why no triangular merger between Chrysler, Daimler-Benz, and a Daimler subsidiary?}

If Daimler-Benz were an American company incorporated under, say, Delaware law it could have agreed with Chrysler a (reverse) triangular merger (cf. CLARK [1986], $430 \mathrm{ff}$;; CARY/EISENBERG [1995], 778; GILSON/BLACK [1995], 641 ff.): A wholly-owned subsidiary of Daimler with stock of its parent company as its assets would be merged into Chrysler. Chrysler's shareholders would get Daimler shares as a consideration for theirs. As a result of such a "reverse triangular merger" all former Chrysler shareholders would hold Daimler-Benz shares; and Chrysler would be a wholly-owned subsidiary of Daimler-Benz.

Why didn't the parties choose this structure? Because German law inhibits (forward as well as reverse) triangular mergers (BAUMS [1998]). The subsidiary of a German stock corporation must not acquire and hold stock of its parent company even for a temporary period of time and only for the purpose of exchanging it for a target's stock ( $71 \mathrm{~d}$ [2] Stock corporation Act). That is also true for foreign subsidiaries.

Hence instead of giving the Chrysler shareholders Daimler shares by means of a merger the Chrysler shareholders will have to bring in their shares into a German company (Oppenheim AG) and get its shares as a consideration. That however, is a complicated and more costly operation: In a first step, the Chrysler shares have to be made available to an American trustee who then signs up for the newly issued Oppenheim shares and brings the Chrysler shares into Oppenheim AG as a contribution in kind ( $\S 183,185$ Stock Corporation Act). The trustee will then hand out these shares or American Depositary Receipts representing these shares to the former Chrysler shareholders. The result will be the same as with a direct triangular merger between Chrysler, Daimler and a Daimler subsidiary. But that way is not viable because of the inflexibility of German corporate law in this respect. Again the parties have to incur higher costs to reach the same result. 


\section{Why don't Chrysler's shareholders bring their shares directly into Daimler- Benz AG?}

As mentioned above, the Chrysler shareholders will - by means of a trustee - bring their shares into a wholly-owned subsidiary of Oppenheim bank rather than directly into Daimler-Benz AG. Later on Daimler-Benz will be merged with this subsidiary (Oppenheim AG). Why is this detour necessary? Because German corporate law leaves room for opportunistic behavior of dissenting shareholders in this point. Bringing shares or other assets into a stock corporation as a contribution in kind in order to get new shares of the respective company as a consideration requires a motion passed by a qualified majority (3/4 of the share capital present) of the old shareholders ( $\$ 186$ Stock Corporation Act). In order to become valid this conclusion must be filed with and registered by the district court (Amtsgericht) in the commercial register ( $\$ 184$ Stock Corporation Act). Assume now that a shareholder holding only one share opposes that conclusion for whatever reason and files an anulment action with the county court $(\S \S 243$, 245, 255 Stock Corporation Act). The district court may then postpone the registration until the civil courts (county court, court of appeal, Federal Civil Court) have delivered their judgments.

For a similar constellation the (more modern) Transformation Act (Umwandlungsgesetz) states that the county court may order that the motion be registered immediately if the anulment action does not lie or apparently proves to be unfounded or if the delay of the registration would be disproportionate given the interests involved ( $\$ 16$ [2], [3] Transformation Act). As there is no such mechanism here, the parties would put their transaction at an unreasonable risk if they chose to bring the Chrysler shares immediately into a publicly held company. Again a costly transaction must be chosen in order to avoid the application of deficient rules allowing opportunistic behavior. An amendment should be made to the Stock Corporation Code similar to that of the new Transformation Act ( $\$ 16$ Umwandlungsgesetz). That would help better exclude opportunistic behavior and at the same time also protect justified interests and objections shareholders might have in cases where new shares are issued to third parties. 


\section{Why no immediate merger of Oppenheim AG and Daimler-Benz AG?}

Daimler-Benz AG will not - according to the reports in the media - be merged immediately into Oppenheim AG. Rather, in a first step Oppenheim AG will issue a public offer to the Daimler shareholders to exchange their shares for Oppenheim shares. Now assume that 80 percent of Daimler's shareholders accept this offer whereas $20 \%$ do not. Oppenheim AG will then hold $80 \%$ of Daimler's shares and with that majority can, in a second step, effect a merger of Daimler into Oppenheim AG ( $\$ 65$ Umwandlungsgesetz). Why this detour, why no immediate merger of Daimler-Benz AG and Oppenheim AG?

There are certainly various arguments. One important argument could be that with an immediate merger all former Daimler shareholders could ask for an improvement of the exchange ratio between Daimler and Oppenheim shares ex post whereas those who accept the public offer cannot. That has to be explained in more detail.

In mergers the exchange ratio between the new shares which the shareholders bringing in their company receive as a consideration, and their old shares which become invalid as a consequence of the merger, is fixed by the managements of the two merging companies. The shareholders of the transferring company who disagree with the exchange ratio may oppose the merger motion. They may also consent. In any event, if the merger motion has been passed by the majority necessary in such cases, they are free to challenge the exchange ratio before the court $(\S \S 15,305 \mathrm{ff}$. Transformation Act). If the court finds the exchange ratio disadvantageously low to the detriment of the shareholders of the transferring company, it will order a cash payment out of the pocket of the company which has taken them over. Such an additional cash payment can perhaps be avoided at least regarding those shareholders who accept the public offer (step one) instead of being merged into Oppenheim later (step two).

The media have already raised the question whether the targeted exchange ratio will be disadvantageous for Daimler's shareholders: They are - according to the news reports - going to receive $57 \%$ of the new Oppenheim (Daimler-Chrysler) shares, Chrysler's shareholders $43 \%$. Market capitalisation of Daimler-Benz was however (one day before the merger plans were published), with $\$ 55$ bn double Chrysler's. On the other hand, Chrysler's profit before tax was DM 7,9 bn (with a turnover of DM 105 bn) in 1997 as compared with Daimler's of DM 4,2 bn (with a turnover of DM 124 bn). 
From the viewpoint of our analysis the question is whether our merger law is defective in providing for judicial review of the exchange ratio. One could argue as follows: A judicial correction ex post of an exchange ratio or of a bonus which has been negotiated by the agents of the parties to the agreement - the shareholders of the merging companies - is a defective, inefficient solution. As long as both parties are independent of each other ${ }^{8}$ and well informed, there is no need to question or correct the bonus or exchange ratio which has been found by the parties. Such a rule, one could argue, will be anticipated and will raise the cost of mergers (in extreme cases: inhibit them).

This argument would however be wrong for two reasons. First, one side may have cheated the other and given misleading or wrong information on the value of the company. In cases of regular asset or share deals the buyer has a warranty-claim to reduce the purchase price or even the right of conversion. That is not however possible in mergers. The right to question the exchange ratio and ask for an additional cash payment takes the place of the remedies given in regular sales.

Furthermore the "agents" who have negotiated the exchange ratio for the shareholders, i.e. the managements of the merging companies, may have personal interests in the merger and therefore not act independently on behalf of their respective shareholders. That may be because they are pursuing a growth rather than a value maximizing strategy or simply because they hope for better payment by the enlarged firm. ${ }^{9}$

For these reasons an independent review of the exchange rate appears to be a justified regulation.

That does not however mean that the solution found here - a public exchange bid as a first step before the actual merger - is a circumvention of this remedy for Daimler's shareholders. If the shareholder who is asked in a public bid to sell or exchange his shares receives the information which must be given to investors in public takeover bids, ${ }^{10}$ and if he is free to accept the offer

Where one company holds shares of the other company and may thus influence the merger motion, other rules will, of course, apply.

As to the Daimler-Chrysler case the media questioned whether the German managers will receive stock options in the new company comparable to Chrysler's. As the merger between Oppenheim and Daimler-Benz has not yet been effected, this is as yet mere speculation. 
or not, there is no need for an ex post review and correction of the bonus or exchange rate offered to him. The question remains, of course, how many Daimler shareholders will accept this bid, and how many will prefer to wait for the merger. information to them. I do not discuss this question here. 


\section{References}

BAUMS, T. [1996], "Corporate Governance Systems in Europe - Differences and Tendencies of Convergence (Crafoord Lecture)," Working paper No. 37. Universitaet Osnabrueck, Institut fuer Handels- und Wirtschaftsrecht.

-- [1998], "Verschmelzung mit Hilfe von Tochtergesellschaften," Working paper No. 58. Universitaet Osnabrueck, Institut fuer Handels- und Wirtschaftsrecht.

BEBCHUK, L.A. and M. ROE [1998], "A Theory of Path Dependence in Corporate Governance and Ownership," Working paper No. 131. Columbia University, School of Law.

CARY, W.L. and M.A. EISENBERG [1988], Cases and Materials on Corporations, 6th ed., Foundation Press: New York.

CLARK, R.C. [1986], Corporate Law. Little, Brown and Co.: Boston, Toronto.

EISENBERG, M.A. [1989], "The Structure of Corporation Law," Columbia Law Review , 89, 1461-1525.

GROSSFELD, B. [1993], Internationales Gesellschaftsrecht. J. v. Staudingers Kommentar zum Buergerlichen Gesetzbuch. 13th ed., Dr. Arthur L. Sellier \& Co - De Gruyter: Berlin.

GUYON, Y. [1996], Droit des affairs, Vol. 1, 9. ed., Paris: Economica.

LARENZ, K. and C.W. CANARIS [1995], Methodenlehre der Rechtswissenschaft. $3^{\text {rd }}$ ed., Springer: Berlin, Heidelberg, New York, Tokyo.

LUTTER, M. (ed.) [1996], Umwandlungsgesetz, Dr. Otto Schmidt: Cologne.

--, H. WIEDEMANN (eds.) [1998], Gestaltungsfreiheit im Gesellschaftsrecht, De Gruyter: Berlin - New York.

ROMANO, R. [1993], The Genius of American Corporate Law, AEI Press: Washington, D.C. 
SCHANZE, E. [1995], "Hare and Hedgehog Revisited: The Regulation of Markets That Have Escaped Regulated Markets," Journal of Institutional and Theoretical Economics (JITE), 151/1, 162-176.

SPINDLER, G. [1998], "Deregulierung des Aktienrechts," Die Aktiengesellschaft, 43, 53-74.

TEUBNER, G. [1989], Recht als autopoietisches System, Suhrkamp: Frankfurt/Main. 